\title{
Measuring Community and University Impacts of Critical Civic Geography: Insights from Chicago
}

Daniel R. Block

Chicago State University

Euan Hague

DePaul University

Winifred Curran

DePaul University, wcurran@depaul.edu

Howard Rosing

DePaul University

Follow this and additional works at: https://via.library.depaul.edu/geofacpubs

Part of the Geography Commons

\section{Recommended Citation}

Block, Daniel R.; Hague, Euan; Curran, Winifred; and Rosing, Howard. (2017) Measuring Community and University Impacts of Critical Civic Geography: Insights from Chicago.

https://via.library.depaul.edu/geofacpubs/1

This Article is brought to you for free and open access by the Geography Department at Digital Commons@DePaul. It has been accepted for inclusion in Faculty Publications - Geography Department by an authorized administrator of Digital Commons@DePaul. For more information, please contact digitalservices@depaul.edu. 


\title{
Measuring Community and University Impacts of Critical Civic Geography: Insights from Chicago
}

\author{
Daniel R. Block, Euan Hague, Winifred Curran, and Howard Rosing
}

\section{QUERY SHEET}

This page lists questions we have about your paper. The numbers displayed at left can be found in the text of the paper for reference. In addition, please review your paper as a whole for correctness.

Q1. Au: Please provide page number for this quotation from Bunge 1971.

Q2. Au: Please spell out what NIFA stands for here on first use.

Q3. Au: Glusac 2015: Please provide page number(s) for this entry.

Q4. Au: Hague, Curran, and the Pilsen Alliance 2008: Please provide date this material was accessed from this URL.

Q5. Au: Schmich 2015: Please provide page number(s) for this article here.

\section{TABLE OF CONTENTS LISTING}

The table of contents for the journal will list your paper exactly as it appears below:

Measuring Community and University Impacts of Critical Civic Geography: Insights from Chicago

Daniel R. Block, Euan Hague, Winifred Curran, and Howard Rosing 
FOCUS: OUT IN THE WORLD: GEOGRAPHY'S COMPLEX RELATIONSHIP WITH CIVIC ENGAGEMENT

\author{
Tracing the Impact of Civic Engagement
}

\title{
5 Measuring Community and University Impacts of Critical Civic Geography: Insights from Chicago
}

\author{
Daniel R. Block \\ Chicago State University
}

\author{
Euan Hague, Winifred Curran, and Howard Rosing \\ 10 DePaul University
}

Geographers have increasingly adopted community-based learning and research into their teaching and scholarly activities since Bunge and Harvey called for an applied public geography that is both useful and challenges societal inequalities. With few exceptions, however, there has been little discussion of methods for measuring this work. Many published assessments focus on

15 the impacts of projects on students, but overlook the impacts on community partners. Impacts on faculty and the larger university community are also often ignored. This article discusses literature on the evaluation of community-university research and service learning from a critical perspective. A discussion of service learning and community-based research (CBR) projects at two Chicago universities, DePaul and Chicago State, is presented. In both cases challenges were encountered to achieve full evaluation of projects, yet both included an evaluation of university and community partners that allowed for

20 assessment of the projects' value to all partners. Key Words: Chicago, community-based research, community engagement, service learning.

$\mathbf{T}$ his article discusses ways to understand the impact of civically engaged geography. In his "Historical Materialist Manifesto" Harvey (1984) called for the development of "an applied peoples' geography, unbeholden to narrow or powerful special interests" (9). Inspired by reactions of radical geographers to positivist geographies of the 1960s, most notably Bunge's urban expeditions (e.g., Bunge 1971;

30 Merrifield 1995), Harvey (1984) promoted a theoretically based practical geography that worked with nonacademics to complete projects designed to "be threaded into the fabric of daily life" but "confront or subvert the power of dominant classes or the state"

35 (7). The discipline of geography is particularly well suited for such work. Geographers focus on patterns and processes seen on the ground. Much geographical research, such as climate change and gentrification, are of great interest to the public and often involves 40 participation by both academics and nonacademics.

For Harvey this practical geography should be framed both by social theory and social justice, deal with day-to-day problems of communities, and be organized and structured not by university research-

45 ers, but by interests emerging from and driven by community groups. This parallels the call by the American Association of Colleges and Universities (AACU 2012) for greater civic engagement by academic institutions. The AACU suggests that service learning is a central pedagogical route to providing students with transformational lessons in community participation and civic life. "While service-learning research initially focused on impact on students," argued the AACU (2012), "higher education service-learning programs have amassed greater understandings about how to establish more democratic, participatory, and reciprocal partnerships" (61).

Geography has a long history of engaging in community-based learning through field work with students. Community geography centers using geographic techniques to solve public problems have opened at Syracuse, Columbus State, and elsewhere (Robinson 2010). Despite these developments, there has been relatively little discussion of how to measure the impacts of such work. Service learning scholarship is helpful in this regard, because evaluation of service learning projects is yielding a wealth of lessons. Critical service learning (CSL) has emerged as a strategy combining service learning with critical and historical analysis of power structures and the origins of social injustice. CSL can be distinguished from traditional service learning by its "social change orientation, working to redistribute power, and developing authentic relationships" (Mitchell 2008, 62). The goal is to "deconstruct systems of power so the need for 
service and the inequalities that create and sustain them are dismantled" (Mitchell 2008, 50)

Literature on community-based research (CBR) as pedagogy suggests that the approach can assist stu80 dents and faculty in developing skills to critically engage with and evaluate the social, political, and economic realities that shape the lives of marginalized, oppressed, and resilient communities (Hofman and Rosing 2007). Contrasting a "radical CBR" service-

85 learning approach built on Freireian principles with less critical approaches, Stoecker (2003) argued that "social justice, service-learning, and participatory research fit together to create a radical CBR model" (39). A key to the success of such a model is recogni-

90 tion that oppression is endemic in our society and that the hierarchal processes in community-based research and teaching are themselves under question and must be continuously evaluated to learn about how communities can most benefit from university resources

95 (Stoecker and Tryon 2009).

The civic geography we present includes research and action, whether involving students or not, that is based in geographic theories and methodologies and works toward countering inequalities in society and

100 promoting positive community change. Examples of civically and community-engaged geography are provided from two Chicago universities: DePaul and Chicago State University (CSU). DePaul is a Catholic university with 25,000 students (15,000 undergradu-

105 ates) that mandates all undergraduates complete one experiential learning course such as an internship or service learning. DePaul's geography program strongly emphasizes service learning and CBR as part of its undergraduate major. CSU is a relatively small

110 public university with around 3,600 students $(2,400$ undergraduates) on Chicago's South Side with a primarily African American student body. CSU's geography program works with community organizations to support research and action promoting community-

115 led development projects. The examples highlight lessons learned from the multiplicity of ways geographers seek to create a civically engaged practical geography.

\section{Measuring Impacts of Civic Geography}

The civic geography of Harvey and Bunge means

120 much more than simply doing research or teaching in communities. They explicitly called for a geography that engages with power structures imposed by "dominant classes or the state" (Harvey 1984, 7). As such, measurement of the impact of civic geography projects

125 must go beyond counting participants to discussions of the impacts of projects on participants and communities seeking to resist oppression. Current thinking in the evaluation of service learning and community engagement has evolved from positioning service

130 learning as a "top-down" activity where students or researchers mainly engage in small-scale service activities designed primarily by the university to activities designed through ongoing partnerships between community members and university personnel (Saltmarsh and Zlotkowski 2011). Despite this, most service learning evaluations, even relatively involved ones, have focused largely on student attitudes and learning rather than on evaluating the experiences of the community organization (e.g., Miller 2013; Spalding 2013; one exception is Oldfield 2008). Such literature offers little insight into how or to what degree such forms of student engagement have subverted unjust power structures to benefit community partners.

\section{Case Study 1: DePaul's “Contested Chicago" Project}

Pilsen is a predominantly Latino immigrant neighborhood on Chicago's Lower West Side threatened by gentrification. Once home to a large Czech and Bohemian population, by the 1960 s suburbanization and immigration created a neighborhood with a strong Mexican American identity. The neighborhood is highlighted as "hot" or "up and coming" by real estate interests, a sentiment confirmed by a New York Times Style column that celebrated Pilsen's vintage clothing resale stores, newly opened craft breweries, and restaurants (Glusac 2015). Meanwhile, local residents have become vigorous in their protests, for example, covering a newly opened coffee shop with slogans such as "Fresh Roasted Gentrification Served Here" (Hague 2015; Schmich 2015). In 2003, the Pilsen Alliance community organization approached DePaul University's Steans Center for Community-Based Service Learning requesting collaboration to better understand how gentrification was reshaping the neighborhood. The result was a partnership with the Department of Geography that, since 2004, has offered an annual service learning course exploring gentrification in Pilsen.

GEO133, Urban Geography Experiential Learning, is taught with a central focus on its Contested ChicagoPilsen Building Inventory Project. The course integrates faculty teaching, service, and research alongside a community partner, the Pilsen Alliance, a social justice organization committed to developing grassroots leadership. The Alliance advocates for "quality public education, affordable housing, government accountability and healthy communities ... using innovative community education tools and programs, direct action organizing campaigns and advocacy initiatives reflecting the popular education philosophy of building social consciousness for personal and social collective transformation" (Pilsen Alliance 2016).

The objectives of GEO 133 are to provide a rich learning experience for undergraduate students, aid Pilsen Alliance in their campaigns around gentrification and affordable housing, and make complex issues like gentrification and policies like tax increment financing and zoning understandable to both students and community residents to promote informed civic engagement. Lectures outline geographical analyses 
190 and theories of gentrification, balancing these with shorter essays from local media that examine the Chicago or Pilsen context. Students prepare discussion notes based on these readings that are used in classroom group work, enabling peer explanation and dis-

195 cussion of the material. Field trips to Pilsen highlight recent disputes over, and locations of, condominium development, housing demolitions, and community activism.

For the service-learning component, every student

200 explores one block of Pilsen. Students visit their blocks, assess the structural qualities of the properties and their current uses, and then collect publicly available zoning, tax, permit, and sales data. After completing the research, students compile and analyze data to produce

205 graphs, charts, and maps for a final report about housing development on their block. Student reports are shared with the Pilsen Alliance, and collated into a single database that now contains ten years of data available to the Pilsen Alliance on demand. The project

210 archives also contain hundreds of photographs, documents, and field notes pertaining to gentrification, housing, and neighborhood change in Pilsen.

\section{Impact on Faculty}

There is little doubt that the Pilsen Building Inventory

215 Project has raised the profile of the Department of Geography internally at DePaul and assisted in the tenure and promotion of Hague and Curran, who have also been recognized by the Pilsen Alliance with their Community Collaborator award. The project's findings have been

220 consolidated into reports, informed a short bilingual book exploring gentrification in Pilsen (Hague et al. 2008), and were presented through local radio, television, and newspapers. Participants have also presented testimony about development in Pilsen to the Chicago City Council's sub-

225 committee on zoning and contributed to YouTube materials that support local campaigns to maintain affordable housing in the community.

\section{Impact on Students}

Through the Steans Center, DePaul offers resources

230 for faculty and students to engage in community-based service learning including action research and advocacy. The undergraduate experiential learning requirement allows GEO 133 to be consistently taught and to nurture a long-term departmental-community

235 partnership with the Pilsen Alliance. This contrasts with the AACU (2012) finding that despite the growth of service-learning curricula across the United States, "the vast majority of courses are still random electives that students encounter in no particular order or time

240 sequencing" (59). Anecdotally, students have told faculty that the methods of data collection and analytical techniques introduced in GEO 133 helped them pursue careers in urban planning, real estate, and community organizing. One alum wrote that his "field work in the neighborhood of Pilsen provided processes and techniques I've used throughout my career. Ten years ... later, I vividly remember the joy I felt from this tangible project that was consequential to peoples' lives; this was the moment I decided to become an urban planner." Further, students feel ownership of the data and expertise about their block and many have said that GEO 133 is one of their most important courses. Comments from anonymous course evaluations give some idea of how working with data to assess gentrification affects students. One student commented, "I never really thought about gentrification or about how certain neighborhoods struggled, until I came to this class," and another noted, "It made me see that the residents who live in Pilsen just want to stay there-they don't want to be kicked out."

Reflecting Mitchell's (2008) call for a CSL with a social change orientation, these students' responses also echo the AACU (2012) finding that "a significant portion of college students are interested in community service that leads to systemic social and political change" (4). What is telling in the case of Contested Chicago is that anecdotally many students are subsequently disappointed that their hard work in Pilsen did not stop gentrification.

\section{Impact on Pilsen}

Assessing the impact of university-community projects on community members is more difficult. A lack of time and resources have prevented a systematic assessment of the impact of the Contested Chicago project on Pilsen residents. Data from the inventory are important to the Pilsen Alliance, however, because they help quantify the process of gentrification, a major concern of longtime neighborhood residents. Maps and data presented at community meetings are commonly supplemented by local knowledge of community members. The power of this type of popular education is its potential to activate residents to craft resistance campaigns and pressure local politicians and others to hear concerns regarding affordable housing. It also helps faculty identify additional areas of research and action relevant to community concerns. An early finding from the GEO 133 data was that approximately 35 percent of homeowners in Pilsen did not claim property tax exemptions to which they were entitled. This resulted in the Pilsen Alliance and the Cook County Assessor hosting workshops to aid residents to claim exemptions, saving low-income residents thousands of dollars. Indeed, one student in the course who owned a property elsewhere in Chicago also found that he was eligible for a property tax refund! Comments from three successive Pilsen Alliance executive directors demonstrate the effects of university support for the organization. The first noted:

We were able to leverage critical data on Pilsen's escalating property taxes and precarious zoning 
designation that made it so attractive for developers to demolish older single-family homes into pricey multiunit condos. This partnership went beyond the collection of data, and provided institutional support and legitimacy in advocacy efforts at the municipal level that was critical in a city and city council that had complete political control over land use and zoning, completely disempowering city residents. (Alejandra Ibañez, Executive Director, 2003-2010)

The second director, a longtime community organizer, explained:

Not long ago, those with an interest in developing Pilsen regardless of the consequences for the residents

315 would claim that it was not clear that gentrification was taking place, thus avoiding a discussion about displacement and discrimination. Today, with the help of Hague's research, we can face the real issues and talk about real solutions. (Nelson Soza, Executive Direc-

320 tor, 2010-2015)

Finally, the current executive director, a former Aldermanic candidate, stated:

The[ir] support and expertise ... helped us and is helping us to appeal decisions and plans made by city

325 planners, and offer feasible alternatives in consensus with our community. (Byron Sigcho, Executive Director, 2016-)

This continued evaluation and action research, systematically incorporating feedback from partners,

330 point to the importance of learning how communities can benefit most from university resources, using geographic theories and methodologies to counter inequalities, challenge power structures, and ultimately promote positive social change.

\section{Case Study 2: Chicago State University's Neighborhood Assistance Center}

$\mathrm{CSU}$ is a public predominately black institution (PBI) primarily serving Chicago's South Side and southern suburbs. In fall 2014, 72 percent of students identified

340 as African American. Seventy percent were female, and 45 percent had at least one dependent. In general, CSU students lead complicated lives that reflect the characteristics of the community that surrounds the university. CSU acknowledges this community posi-

345 tion with a mission that adds community development to the traditional triumvirate of teaching, research, and service. CSU hosts a medium-sized geography program. Until recently, CSU hosted the only MA in Geography at a PBI in the United States.

350 Since its beginning in the 1970s, the program has had a focus on civic participation, influenced by Fred Blum, its founding chair. The most lasting impact of this focus was the creation of the Fredrick Blum Neighborhood Assistance Center (NAC) to foster

355 self-reliant community development. This is accomplished through assisting in the development of neighborhood planning projects and networks, performing surveys and other analyses, and cartographic and geographic information systems (GIS) assistance. Small projects are performed for free by NAC staff, student workers, and faculty, whereas larger projects might be grant-funded, usually in partnership with community organizations. Although the NAC does connect organizations with service learning opportunities within classes, more often students interact with the community through the NAC through internship placements or research assistantships and fellowships that involve community-based learning. Although it predated the term, the NAC could be considered a community geography center.

Much of the NAC's work during the past ten years has been focused on food access, but other projects have included partnering with the Chicago Community Health Worker Local Network and the Chicago Department of Public Health, among others, on a survey of community health workers and a current project focusing on the redevelopment of a dilapidated commuter train stop near campus. A current long-term project is support for and coordination of the Roseland-Pullman Urban Agriculture Network, a network of community gardeners and urban agriculture practitioners on Chicago's Far South Side. Grants are usually primarily for student support, which is particularly important at CSU with its large population of nontraditional students with dependents. Service learning can be difficult because of the extramural obligations of many of the students (Block and Bouman 2007).

Measurement of the impacts of the NAC's work have included a university-based annual evaluation tied to the center's goals that primarily includes quantitative measures such as the number of grants applied for, the number of community-university collaborations supported, and the number of maps and other projects completed. This evaluation is important for internal and external reporting purposes, but the strictly quantitative nature means that it does not include deeper stories of the outcomes of the NAC's community engagement. For instance, three gardeners and urban agriculture practitioners who met through the urban agriculture network pooled resources to purchase a load of compost, the cost of which would otherwise have been prohibitive. In another example, a longtime partnership with food justice activists and the City of Chicago led to questions being added to City of Chicago grocery health inspections regarding availability of fresh produce and meats that can be mapped using the city's online data system (Castillo et al. 2013).

Such stories, typically backed with quantitative geographic data, are also part of NAC's project-based evaluations that occur as a result of the Center's grant funding. For instance, a U.S. Department of Agriculture grant helped support outreach and curriculum development related to CSU's aquaponics center, which was installed in 2012 in an old shoe warehouse a few blocks from the main campus. The goal of the grant was to help CSU become the nexus of a South Side urban agriculture network, through curriculum 
development, workshops for the public, and networking, with the aquaponics center serving as a spark for curriculum development, research, and student and

\section{0 community engagement.}

Evaluation of the South Side Urban Agriculture project was contracted with the Egan Urban Center (EUC) at DePaul University and involved interviews with CSU students, faculty, and community partners. Researchers

425 employed a participatory evaluation approach structured to examine (1) program design and relevance to local needs, (2) management, (3) effectiveness at achieving its objectives, (4) impact on the direct and indirect beneficiaries, (5) satisfaction of the stakeholders, and (6) sustain-

430 ability of the project, its results, and impact.

\section{Impact on Faculty}

CSU faculty expressed support for the project. For example, a CSU professor was especially pleased that the program was firmly embedded in the geography

435 and biology departments and saw opportunities to further integrate work with community partners into curriculum:

I believe the strongest success of this project has been the community engagement and outreach work. But there are also many opportunities that have been created through the project in the university as well. The design of the curriculum is solid. (Zeigler and Rosing 2017)

Geography, multidisciplinary by design, is particu445 larly well suited to develop curriculum and recruit teaching and support staff that serve the interest of both students and communities.

Evaluation of the South Side Urban Agriculture Network also highlighted challenges faced by faculty who, for

450 example, expressed concerns about course loads and administrative responsibilities that make undertaking a community engagement program less desirable. This is especially the case when departments are understaffed or do not have faculty who have the expertise to respond to

455 the often varied and multidisciplinary interests of community partners. The latter highlights a fissure between higher education curriculum and the practical interests in communities that do not necessarily align with disciplinary boundaries. Indeed, "an applied peoples' geography,

460 unbeholden to narrow or powerful special interests" (Harvey 1984, 9) requires new interdisciplinary ways of thinking about curriculum and faculty hires to meet demands of a theoretically based practical geography that works with nonacademics on projects designed, as Harvey

465 noted, to "be threaded into the fabric of daily life" while confronting or subverting power.

\section{Impact on Community Partners}

Community partners expressed that participation in the network led to learning from each other, creating 470 a community of gardeners working to build better urban agriculture practices. This type of support is particularly needed in the neighborhoods surrounding CSU, where availability of fresh food is low and gardeners play an important role in contributing to the nutritional wellness of households and communities. Gardeners learned about resources available to support their work and independently formed collaborations with each other. Technical assistance sessions provided relevant information and offered insight into the potential for future expansion of the partners' agricultural initiatives. One community partner commented, "Farming is a hard enterprise. Community farming in a difficult neighborhood is hard. We got lots of support and help from other farmers in the network, from ... [CSU] ... and from the technical assistance and workshops. The support was very important. The information and resource sharing was invaluable. This is the way to go for community farms" (Zeigler and Rosing 2017).

As in the case of Pilsen, the "invaluable" quality of grant-funded, capacity-building geography projects in economically distressed spaces lies not so much in the data produced as in the intangible contributions made to community development. CSU's partners noted the desire for more assistance with, for example, urban farm management, improving garden production, negotiating with potential consumers such as local schools, and paid positions (rather than volunteers) for farm and garden managers. The partners suggested that assistance with marketing their projects in the community could help them gain more participation from the local population.

Notwithstanding the benefits of grant-funded, community-based geography projects, there are also clear drawbacks given their foundation in temporal funding arrangements that can lead to challenges in consistency, scope, and depth of outreach. Gardeners expressed concerns that there was not always continuity between network meetings and that information was sometimes redundant. Some complained that other participants were not always actively involved, that the seed grants were modest in size given the record-keeping demands, and that it often took too long to receive payment. They wanted more coordination of project activities, improved cohesiveness among participants, and more assistance navigating bureaucracy and regulations underlying food production and land tenure. Such sentiments point to the need for more institutionalized forms of engagement.

\section{Conclusion}

Bunge (1971) noted, "geography is great and why don't geographers do some of it?" At both DePaul and $\mathrm{CSU}$, geographers are engaging with the social and economic contexts of surrounding communities in ways that are relevant to people's daily lives. As with Bunge's Expeditions, the purpose at both these departments is to compile data "to promote community 
activism and enhance local empowerment" (Merrifield 1995, 56). Yet service learning and CBR must be 530 understood through a critical lens, beginning with training faculty and staff to understand the power differential inherent in relationships between large higher education institutions and small, typically understaffed, financially vulnerable, community

535 organizations (Mitchell 2008, 56-57). Calls for building "true community-university partnerships" (Mitchell 2008, 52) where community issues are as important as student learning are complicated by power imbalances leaning toward higher education

540 institutions that themselves face internal challenges that hinder community engagement. Geographers can have a role in brokering those power imbalances.

Although the two Chicago examples are academic exercises in the coproduction of knowledge by the

545 community, students, and faculty, the academy does not necessarily recognize such projects as scholarship. Indeed, in each case, instead of focusing on peerreviewed articles, we instead produce analyses that are accessible to the community. This approach highlights

550 the critical question of how academics and specifically geographers value civic work in an institutional environment in which "impact factors" and other quantitative measures of scholarship devalue such long-term civically engaged service learning and action research

555 projects, and universities rarely offer faculty the time to develop community relationships (cf. Mountz et al. 2015). As geographers pursue more civically engaged projects, there will likely be new debates concerning what constitutes scholarship in the discipline and

560 which new techniques can aid in sharing knowledge with communities. Publications such as this perhaps suggest that geography and the wider academy will, in the future, place more scholarly value on civic engagement.

\section{Acknowledgments}

Daniel Block and Howard Rosing would like to thank the U.S. Department of Agriculture NIFA program, which helped sponsor the Chicago South Side Urban Agriculture Initiative. Block and Rosing would also

570 like to thank the students, faculty, and community organizations that participated in the initiative and consented to interviews about it. Euan Hague. Winifred Curran, and Howard Rosing would like to thank the Pilsen Alliance and the students who have

575 completed GEO 133 at DePaul University. Hague and Curran's work in Pilsen has also been supported by a Community-Based Research Fellowship from DePaul University's Steans Center for CommunityBased Service Learning.

\section{Literature Cited}

Association of American College and Universities. (AACU). 2012. The National Task Force on Civic Learning and
Democratic Engagement: A crucible moment. College learning and democracy's future. Washington, DC: AACU.

Block, D., and M. Bouman. 2007. Paradoxes of praxis: Community-based learning at the community based university. In Pedagogies of praxis: Course-based action research in the social sciences, ed. N. G. Hofman and $\mathrm{H}$. Rosing, 95-100. Bolton, MA: Anker.

Bunge, W. 1971. Fitzgerald: Geography of a revolution. Cambridge, MA: Schenkman.

Castillo, S. R., D. Block, C. Cort, and S. Krauss. 2013. Letter to the editor: Innovation in the collection of food availability data: A case study of the Chicago Department of Public Health Sanitarian Survey. Preventive Medicine 57:70-71.

Glusac, E. 2015. A Chicago neighborhood follows a Latin beat. New York Times 28 January.

Hague, E. 2015. Pilsen: Chicago's gentrifying lower west side. In Out of the loop: Vernacular architecture foundation, ed. V. B. Price, D. A. Spatz, and D. B. Hunt, 99-103. Chicago: Agate.

Hague, E., W. Curran, and the Pilsen Alliance. 2008. Contested Chicago: Pilsen and gentrification/Pilsen y el aburguesamiento: Una lucha para conservar nuestra comunidad. www.lulu.com.

Harvey, D. 1984. On the history and present condition of geography: An historical materialist manifesto. The Professional Geographer 36 (1):1-11.

Hofman, N. G., and H. Rosing. 2007. Pedagogies of praxis: Course-based action research in the social sciences. Bolton, MA: Anker.

Merrifield, A. 1995. Situated knowledge through exploration: Reflections on Bunge's "Geographical Expeditions." Antipode 27 (1):49-70.

Miller, G. 2013. Education for citizenship: Community engagement between the Global South and the Global North. Fournal of Geography in Higher Education 37 (1):44-58.

Mitchell, T. D. 2008. Traditional vs. critical service-learning: Engaging the literature to differentiate two models. Michigan Journal of Community Service Learning 2008 (Spring):50-65.

Mountz, A., A. Bonds, B. Mansfield, J. Loyd, J. Hyndman, M. Walton-Roberts, R. Basu, et al. 2015. For slow scholarship: A feminist politics of resistance through collective action in the neoliberal university. ACME: An International EJournal for Critical Geographies 14 (4):1235-59.

Oldfield, S. 2008. Who's serving whom? Partners, process, and products in service-learning projects in South African urban geography. Fournal of Geography in Higher Education 32 (2):269-85.

Pilsen Alliance. 2016. The Pilsen Alliance: About us. Accessed February 7, 2016. http://www.thepilsenalliance. org/about-us/

Robinson, J. 2010. Syracuse community geography: Evaluating a new approach to public participation geographic information systems. Unpublished PhD dissertation, University of North Carolina at Chapel Hill, Chapel Hill, NC.

Saltmarsh, J., and E. Zlotkowski. 2011. Introduction: Putting into practice the civic purposes of higher education. In Higher education and democracy, ed. J. Saltmarsh and E. Zlotkowski, 1-8. Philadelphia: Temple University Press.

Schmich, M. 2015. Pilsen coffee shop becomes target of antigentrification. Chicago Tribune 27 January 2015.

Spalding, R. 2013. "Daring to volunteer": Some reflections on geographers, geography students and evolving institutional support for community engagement in higher education. Fournal of Geography in Higher Education 37 (1):59-64. 
650

Stoecker, R. 2003. Community-based research: From practice to theory and back again. Michigan fournal of Community Service Learning 9 (2):35-46.

Stoecker, R., and E. A. Tryon, with A. Hilgendorf, eds. 2009. The unheard voices: Community organizations and service learning. Philadelphia: Temple University Press.

Zeigler, J., and H. Rosing. 2017. Evaluation of Chicago South Side urban agriculture initiative. Unpublished report. Neighborhood Assistance Center, Chicago State University, Chicago, IL.

660 DANIEL R. BLOCK is a Professor of Geography and Coordinator of the Fredrick Blum Neighborhood Assistance Center at Chicago State University, Chicago, IL 60628. E-mail: dblock@csu.edu. With Howard Rosing, he is the coauthor of Chicago: A Food Biography (2015). He is also the author or

665 coauthor of numerous articles on urban food systems and community-based research.
EUAN HAGUE is Professor and Chair of the Department of Geography at DePaul University, Chicago, IL 60604. E-mail: ehague@depaul.edu. He is an urban and cultural geographer, who most recently coedited Neoliberal Chicago (2017).

WINIFRED CURRAN is an Associate Professor of Geography at DePaul University, Chicago, IL 60604. E-mail: wcurran@depaul.edu. She is the author of Gender and Gentrification (2017).

HOWARD ROSING is the Executive Director of the Steans Center for Community-Based Service Learning at DePaul University, Chicago, IL 60604. E-mail: hrosing@depaul.edu. $\mathrm{He}$ is a faculty member in Community Service Studies and affiliate faculty member in Geography, Sustainable Urban Development and Community Psychology. His research focuses on urban food access, community food systems, and food justice movements in Chicago and the Dominican Republic. 